\title{
Pengembangan LKPD Berbasis Masalah Open Ended untuk Menumbuhkan Berpikir Kreatif Peserta Didik Kelas X dan Menunjang Pembelajaran Daring
}

\author{
Maulana Fatiehurrizqie Arrasyid, Karim, Asdini Sari
}

Pendidikan Matematika, FKIP, Universitas Lambung Mangkurat

rizqie.arrasyid@gmail.com

\begin{abstract}
This study aims to produce teaching materials in the form of open-ended problem-based student worksheets on trigonometry material to support online learning and foster creative thinking skills in class X students and find out the responses of teachers and students to the developed student worksheets. This study used a 4-D model, but only three out of four stage are done which are define, design, and develop. Data collection techniques were carried out using validation sheets and questionnaires for teacher and student. Validation was carried out by three experts and the response questionnaire was tested in response to five teachers and five students. The data obtained will be analyzed qualitatively and quantitatively. The score obtained from the validation sheet is $88.14 \%$ with very valid criteria. While the score obtained from the teacher response questionnaire is the number of teachers whose scores are in the practical category more than the number of teachers whose scores are in the impractical category and the score obtained from the student response questionnaire is the number of students whose scores are in the readable category more than the total number of students whose scores fall into the illegible category. This means that student worksheets meets the criteria of practicality and legibility.
\end{abstract}

Keywords: creative thinking; student worksheets; open ended; online learning

\begin{abstract}
Abstrak
Penelitian ini bertujuan menghasilkan bahan ajar berupa LKPD berbasis masalah open ended pada materi trigonometri untuk menunjang pembelajaran daring dan menumbuhkan kemampuan berpikir kreatif pada peserta didik kelas X serta mengetahui respon dari guru dan peserta didik terhadap LKPD yang dikembangkan. Penelitian ini dilakukan dengan menggunakan model pengembangan 4-D, namun tahapan yang dilakukan terbatas pada tahap define, design, dan develop. Teknik pengumpulan data dilakukan menggunakan lembar validasi serta angket respon guru dan peserta didik. Validasi dilakukan oleh tiga orang ahli dan angket respon di uji responkan kepada lima orang guru dan lima orang peserta didik. Data yang didapat akan dianalisis secara kualitatif dan kuantitatif. Skor yang didapat dari lembar validasi adalah 88,14\% dengan kriteria sangat valid. Sedangkan skor yang didapat dari angket respon guru adalah jumlah guru yang nilainya masuk pada kategori praktis lebih dari jumlah guru yang nilainya masuk pada kategori tidak praktis dan skor yang didapat dari angket respon peserta didik adalah jumlah peserta didik yang nilainya masuk pada kategori terbaca lebih dari jumlah peserta didik yang nilainya masuk pada kategori tidak terbaca. Artinya LKPD memenuhi kriteria kepraktisan dan keterbacaan.
\end{abstract}

Kata Kunci: berpikir kreatif; LKPD; open ended; pembelajaran daring 


\section{PENDAHULUAN}

Salah satu hal yang teramat penting dalam kehidupan adalah pendidikan. Pendidikan yang bisa mengembangkan peserta didik adalah lewat pelajaran matematika. Kharisma \& Asman (2018) juga menerangkan bahwa matematika merupakan ilmu dasar yang berperan penting dalam perkembangan kehidupan. Maka dari itu pembelajaran matematika hendaknya disajikan kepada semua peserta didik dimulai dari sekolah dasar, yang akan bermanfaat melengkapi peserta didik dengan kemampuan berpikir tingkat tinggi yang salah satunya adalah kreatif.

Berpikir kreatif adalah salah satu kemampuan yang penting dimiliki setiap orang untuk dapat bersaing secara global. Menggunakan masalah matematika open ended adalah salah satu alternatif yang bisa dipakai guru untuk menumbuhkan kreativitas peserta didik. Cakır \& Cengiz (2016) juga menyatakan bahwa penggunaan masalah open ended dapat menumbuhkan partisipasi peserta didik dalam pembelajaran dan dapat memaksimalkan kognitif dan kemampuan berpikir kreatif mereka.

Trisnawati dkk (2018) mengemukakan bahwa materi dalam matematika yang membutuhkan kompetensi berpikir kreatif seperti yang dijelaskan sebelumnya salah satunya adalah trigonometri. Materi trigonometri disajikan pada tingkat SMA kelas X semester II (Permanasari dkk, 2013). Nuryadi dkk (2018) juga mengemukakan bahwa materi trigonometri ini sangat penting karena berguna untuk mempelajari materi yang tingkatannya lebih sulit, seperti limit fungsi, turunan fungsi, integral, dan dimensi tiga. Akan tetapi, trigonometri juga dapat dikatakan salah satu materi matematika yang sangat susah dipahami sebagian besar peserta didik (Yunian Putra \& Anggraini, 2016). Karena, trigonometri masih bersifat abstrak dan mempunyai tingkat kesukaran tersendiri Nurcikawati (2018).

Tidak semua soal matematika merupakan masalah matematika. Soal matematika yang tidak bisa dipecahkan dengan cara biasa yang sudah diketahui peserta didik dikenal dengan istilah masalah matematika. Masalah matematika open ended adalah masalah matematika yang memungkinkan adanya banyak alternatif cara penyelesaian atau banyak alternatif jawaban.

Livne, Livne \& Wight (2008) memaparkan kembali pendapat JP Becker \& S Shimada (1997) tentang keunggulan dari penggunaan masalah matematika open ended dalam pembelajaran. Keunggulan tersebut adalah berpikir kreatif peserta didik dapat berkembang signifikan. Ariani dkk (2014) dan Bahar \& June Maker (2015) juga menerangkan dimana penggunaan masalah matematika open ended mampu menumbuhkan kreativitas peserta didik, pada proses pembelajaran peserta didik lebih aktif, dan peserta didik lebih percaya diri untuk menyampaikan argumentasinya.

Membuat matematika menjadi masalah open ended bukanlah hal yang mudah. Untuk membuatnya perlu ditelaah banyak cara penyelesaian atau banyak penyelesaian yang mungkin, agar kemampuan berpikir kreatif pada peserta didik dapat meningkat. Oleh 
karena itu diperlukan skema pembelajaran yang terintegrasi serta bahan ajar yang tepat untuk mendukung kegiatan pembelajaran tersebut. Terbatasnya hubungan antara guru dan peserta didik dikarenakan pembelajaran daring (dalam jaringan) karena adanya surat edaran dari Kemendikbud yang berisi tentang Pelaksanaan kegiatan belajar mengajar dalam masa pandemi Covid-19, membuat guru harus bekerja lebih keras supaya kegiatan belajar mengajar tetap terlaksana dengan semestinya.

Bersumber pada hasil interviu dengan guru matematika di SMAN 5 Banjarmasin, SMAN 10 Banjarmasin, SMAN 13 Banjarmasin, dan SMAN 1 Alalak, selama pembelajaran daring guru membuat bahan ajar yaitu LKPD (lembar kerja peserta didik) sebagai penunjang dalam proses mengajar daring. Namun, karena pada situasi belajar daring LKPD yang dibuat belum bisa membuat peserta didik menjadi lebih kreatif, aktif dan berani mengemukakan pendapatnya. Hal ini di rasa cocok oleh peneliti untuk mengembangkan LKPD berbasis masalah open ended.

Penelitian terdahulu yang mengembangkan LKPD berbasis masalah open ended diantaranya dilakukan oleh Khairul dkk (2018) dan Putra (2019) kedua penelitian ini lebih fokus pada LKPD berbasis masalah open ended secara umum sedangkan Yasmin (2019) telah mengembangkan LKPD berbasis masalah open ended untuk menumbuhkan kemampuan berpikir kreatif matematis pada peserta didik SMP. LKPD yang dikembangkan dalam penelitian ini beda dengan penelitian sebelumnya. Perbedaan pertama, pada telaah pustaka belum ditemukan pengembangan LKPD berbasis masalah open ended yang secara spesifik dimaksudkan untuk menumbuhkan kemampuan berpikir kreatif pada peserta didik SMA. Perbedaan kedua, pada telaah pustaka juga belum ditemukan pengembangan LKPD berbasis masalah open ended untuk menunjang pembelajaran daring. Oleh karena itu pengembangan LKPD berbasis masalah open ended untuk menunjang pembelajaran daring dan menumbuhkan kemampuan berpikir kreatif pada peserta didik SMA merupakan hal yang baru dan perlu dilakukan. Maksud dari penelitian ini adalah Menghasilkan LKPD berbasis masalah open ended untuk menunjang pembelajaran daring dan menumbuhkan kemampuan berpikir kreatif pada peserta didik SMA kelas X yang valid juga mengetahui presepsi guru dan peserta didik berkenaan dengan LKPD yang dikembangkan.

\section{METODE PENELITIAN}

Penelitian ini memakai metode Research and Development dengan model Thiagarajan et al. (1974) atau disebut juga. Terdapat empat tahap yang mencakup tahap define, design, develop, dan disseminate. Namun dari keempat tahapan tersebut hanya tiga tahapan yang dilaksanakan dalam penelitian ini, yaitu sampai tahap develop penilaian ahli karena dalam situasi pandemi covid-19, dan tidak dilakukan pada tahap disseminate karena keterbatasan waktu dan sumber daya.

Adapun pengembangan media pembelajaran pada penelitian ini memiliki prosedur dengan langkah-langkah seperti yang tertera pada gambar 1 di bawah ini. 


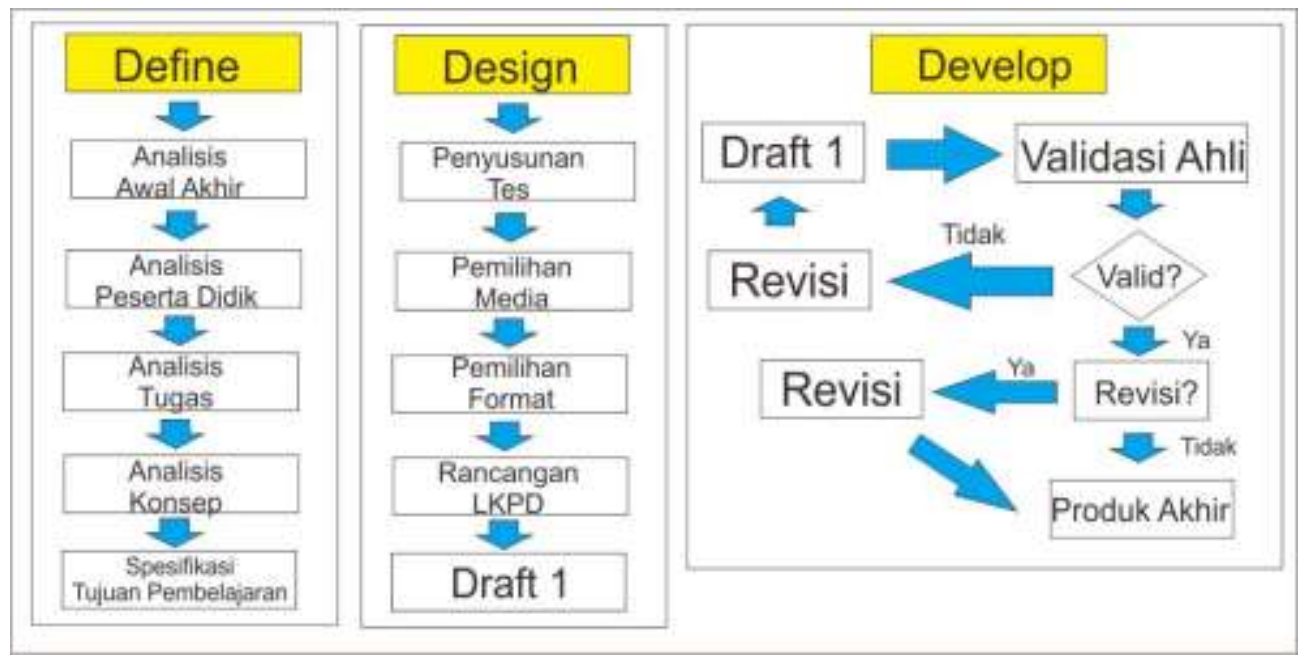

Gambar 1. Prosedur Pengembangan Model 4-D

Ada dua tipe data yang akan dianalisis dalam penelitian ini, yaitu data kualitatif yang berupa kritik dan saran dari validator, kemudian data kuantitatif yang berupa perolehan nilai dari lembar validasi serta angket respon guru dan peserta didik. Uji validasi dilakukan tiga orang ahli yang terdiri dari dua orang dosen Universitas Lambung Mangkurat dan satu orang guru SMAN 5 Banjarmasin. Penilaian lembar validasi menggunakan persentase. Berikut rumus menghitung persentase (\%) kevalidan menurut Akbar (2017).

$$
V_{a}=\frac{S_{d}}{S_{m}} \times 100 \%
$$

Keterangan:

$V_{a}=$ Validasi Ahli

$S_{d}=$ Total skor yang diperoleh

$S_{m}=$ Total skor maksimal

Selanjutnya, untuk menentukan kevalidan dari LKPD yang dikembangkan, nilai $\left(V_{a h}\right)$ dirujuk ke tabel 1 yang diadaptasi dari Akbar (2017).

Tabel 1. Kriteria Validitas

\begin{tabular}{ccc}
\hline No & Kritera Vakiditas & Tingkat Validitas \\
\hline 1 & $85,01 \%-100,00 \%$ & Sangat Valid \\
\hline 2 & $70,01 \%-85,00 \%$ & Cukup Valid \\
\hline 3 & $50,01 \%-70,00 \%$ & Kurang Valid \\
\hline 4 & $01,01 \%-50,00 \%$ & Tidak Valid \\
\hline
\end{tabular}

Berdasarkan tabel tersebut, LKPD disimpulkan valid oleh para ahli bila nilai rata-rata jatuh ke dalam kategori cukup valid dan sangat valid. Selanjutnya LKPD diuji responkan kepada guru untuk mengetahui kepraktisan dan diuji responkan kepada peserta didik untuk mengetahui keterbacaan LKPD yang dikembangkan. Uji respon menggunakan 
rating scale dengan skala 1-4. Data dari angket dipakai untuk mengukur respon guru dan peserta didik mengenai LKPD yang telah dikembangkan. Tiap butir pertanyaan diberi skor berdasarkan tabel 2 berikut.

Tabel 2. Skor Skala Likert

\begin{tabular}{ccc}
\hline Penilaian & Rata-Rata Penilaian Para Ahli & Tingkat Validitas \\
\hline STS & Sangat Tidak Setuju & Sangat Valid \\
\hline TS & Tidak Setuju & Cukup Valid \\
\hline S & Setuju & Kurang Valid \\
\hline SS & Sangat Setuju & Tidak Valid \\
\hline
\end{tabular}

Data yang di dapat dari respon guru dan peserta didik didikotomikan menjadi 2 kategori, untuk hasil respon guru dikategorikan menjadi praktis dan tidak praktis sedangkan untuk hasil respon peserta didik dikategorikan menjadi terbaca dan tidak terbaca.

LKPD dikatakan praktis jika nilai yang diberikan guru berada di atas nilai rata-rata. Sedangkan jika di bawah rata-rata dikategorikan tidak praktis dan LKPD dikatakan terbaca jika nilai yang diberikan peserta didik berada di atas rata-rata. Sedangkan jika di bawah rata-rata dikategorikan tidak terbaca.

Analisis secara keseluruhan, LKPD memenuhi kriteria kepraktisan jika jumlah guru yang nilai dari angket responnya berada pada kategori praktis lebih dari jumlah guru yang nilai dari angket responnya berada pada kategori tidak praktis dan LKPD memenuhi kriteria keterbacaan jika jumlah peserta didik yang nilai dari angket responnya berada pada kategori terbaca lebih dari jumlah peserta didik yang nilai dari angket responya berada pada kategori tidak terbaca.

\section{HASIL DAN PEMBAHASAN}

Tahapan penelitian adalah sebagai berikut.

\subsection{Tahap Define}

Tahap define mencakup beberapa kegiatan yang dijelaskan sebagai berikut.

\section{Analisis awal-akhir}

Hasil interviu dengan guru mata pelajaran matematika di SMAN 5 Banjarmasin, SMAN 10 Banjarmasin, SMAN 13 Banjarmasin, dan SMAN 1 Alalak. Diperoleh informasi selama pembelajaran daring sumber belajar yang dipakai berbentuk buku paket dan LKS yang berisi contoh soal, materi dan soal-soal lainnya yang belum mampu membuat peserta didik berpikir lebih kreatif untuk menyelesaikan permasalahan dari setiap soal tersebut. Oleh karena itu, penggunaan masalah open ended dapat menjadi salah satu pilihan yang bisa dipilih karena bisa menumbuhkan kemampuan berpikir kreatif peserta didik (Cakir \& Cengis, 2016).

\section{Analisis peserta didik}


Bersumber dari hasil interviu dengan guru di SMAN 5 Banjarmasin, SMAN 10 Banjarmasin, SMAN 13 Banjarmasin, dan SMAN 1 Alalak selain permasalahan internet, peserta didik juga kurang disiplin, kurang tertarik dengan pembelajaran daring dan hanya terbiasa menyelesaikan soal yang sama dengan yang dicontohkan, kesulitan dalam belajar secara mandiri untuk memahami konsep dari suatu materi pembelajaran yang diberikan guru. Sehingga, penggunaan LKPD yang menarik untuk menunjang pembelajaran daring akan membuat peserta didik bisa antusias belajar secara mandiri untuk memahami suatu pembelajaran yang diajarkan oleh guru.

\section{Analisis tugas}

Tahap ini disusun berdasarkan dan indikator pencapaian kompetensi materi trigonometri untuk kelas X juga kompetensi dasar dengan standar isi kurikulum 2013. LKPD dikembangkan dibagi menjadi dua bagian kegiatan yaitu, (1) kegiatan 1: konsep tigonometri; dan (2) kegiatan 2: menyelesaikan masalah yang berkaitan dengan trigonometri.

\section{Analisis konsep}

Tahap ini dimulai dari menganalisis konsep trigonometri dengan meninjau silabus kurikulum 2013 yang terdapat pada lampiran 1. Hasil analisis konsep menunjukan bahwa kompetensi dasar yang harus dimiliki peserta didik yaitu memahami dan menganalisis terkait dengan trigonometri dan menyelesaikan masalah yang berkenaan dengan trigonometri. Materi yang diajarkan dalam konsep trigonometri meliputi konversi sudut, nilai perbandingan sudut, identitas trigonometri, relasi sudut, aturan sinus dan cosinus, serta grafik fungsi dari trigonometri.

\section{Spesifikasi tujuan pembelajaran}

Tujuan pembelajaran dengan kompetensi dasar (KD) dan indikator pencapaian kompetensi (IPK) yang tercantum dalam RPP dan silabus.

\subsection{Tahap Design}

\section{Penyusunan tes}

Penyusunan tes mengacu pada kriteria kompetensi yang harus dicapai berdasarkan spesifikasi tujuan pembelajaran.

\section{Penyusunan media}

Pemilihan media digunakan untuk memudahkan peserta didik memahami konsep dan menyelesaikan masalah yang disajikan pada LKPD. Media yang dipilih untuk LKPD ini adalah fitur workbooks pada website www.liveworksheets.com untuk membagikan LKPD ini sebagai bahan ajar pembelajaran daring.

\section{Pemilihan format}

Format yang digunakan dalam perancangan LKPD ini merujuk pada penggunaan masalah matematika open ended dengan pokok bahasan trigonometri. Kegiatan belajar dalam LKPD diawali dengan mengonversi sudut dari derajat ke radian ataupun 
sebaliknya. Soal-soal yang dibuat dalam LKPD berbentuk masalah dengan level kognitif penalaran yang meliputi (C4) dan mengevaluasi (C5).

\section{Rancangan Awal}

Perancangan awal LKPD ini dilakukan pembuatan desain untuk cover serta desain setiap halaman LKPD menggunakan aplikasi microsoft word. LKPD dibuat di kertas A4 dengan jenis huruf untuk cover menggunakan Calibri, Times New Roman, dan Cooper Std Black. Jenis huruf untuk isi dan penutup menggunakan Times New Roman, Comic Sans MS, dan Cambria Math. LKPD dapat dilihat pada link berikut https://www.liveworksheets.com/myworkbooks/

\subsection{Tahap Develope}

Tahap terakhir adalah tahap pengembangan yang mencakup perbaikan draft LKPD berdasarkan uji validatitas. Validator terdiri dari dua dosen Universitas Lambung Mangkurat dan satu orang guru matematika SMAN 5 banjarmasin. Berdasarkan saransaran validator, dilakukan perbaikan terhadap draf I. Hasil revisi ini untuk mendapatkan produk akhir yang valid. Tabel 3 menunjukan hasil rekapitulasi nilai dari validator berkaitan dengan LKPD yang dikembangkan. Berdasarkan data tersebut dapat diketahui produk akhir berupa LKPD yang valid berdasarkan persentase rata-rata seluruh aspek yaitu $88,14 \%$.

Tabel 3. Rekapitulasi Penilaian LKPD

\begin{tabular}{|c|c|c|c|c|c|c|c|c|}
\hline \multirow{7}{*}{ LKPD } & \multirow{2}{*}{ Aspek } & \multicolumn{3}{|c|}{ Validator } & \multirow{2}{*}{$\begin{array}{c}\text { Jumlah skor } \\
\text { diperoleh }\end{array}$} & \multirow{2}{*}{$\begin{array}{l}\text { Total skor } \\
\text { maksimal }\end{array}$} & \multirow{2}{*}{$\%$} & \multirow{2}{*}{ Kriteria } \\
\hline & & 1 & 2 & 3 & & & & \\
\hline & A & 15 & 19 & 20 & 54 & 60 & 90,00 & $\begin{array}{c}\text { Sangat } \\
\text { Valid } \\
\end{array}$ \\
\hline & B & 16 & 19 & 20 & 55 & 60 & 91,66 & $\begin{array}{c}\text { Sangat } \\
\text { Valid }\end{array}$ \\
\hline & $\mathrm{C}$ & 27 & 33 & 31 & 91 & 108 & 84,25 & $\begin{array}{l}\text { Cukup } \\
\text { valid }\end{array}$ \\
\hline & D & 21 & 28 & 26 & 75 & 84 & 89,28 & $\begin{array}{c}\text { Sangat } \\
\text { Valid }\end{array}$ \\
\hline & Jumlah & 79 & 99 & 97 & 275 & 312 & 88,14 & $\begin{array}{c}\text { Sangat } \\
\text { Valid }\end{array}$ \\
\hline
\end{tabular}

Selanjutnya LKPD yang telah dinyatakan valid diujicobakan kepada kelompok kecil di lapangan. LKPD diresponkan kepada lima orang guru mata pelajaran matematika di SMA/MA guna mengetahui tingkat kepraktisan LKPD dan lima orang peserta didik guna mengetahui tingkat keterbacaan LKPD yang dikembangkan. Masing masing repsonden diberikan link media pembelajaran beserta lembar angket respon yang diisi dengan cara memberi centang pada skor yang dirasa sesuai. Adapaun rekapitulasi respon dari lima orang guru dan lima orang peserta didik dapat dilihat pada tabel-tabel 4 dan 5 di bawah ini. 
Tabel 4. Rekapitulasi Respon Guru Terhadap LKPD

\begin{tabular}{ccccccc}
\hline \multirow{2}{*}{ Aspek } & \multicolumn{5}{c}{ Guru } & Rata-Rata \\
\cline { 2 - 6 } & 1 & 2 & 3 & 4 & 5 & \\
\hline A & 12 & 12 & 12 & 12 & 12 & \\
\hline B & 34 & 32 & 33 & 35 & 34 & \multirow{2}{*}{74,8} \\
\hline C & 14 & 15 & 14 & 15 & 16 & \\
\hline D & 15 & 13 & 15 & 15 & 14 & \\
\hline Jumlah & 75 & 72 & 74 & 77 & 76 & \\
\hline
\end{tabular}

Berdasarkan tabel 4 di atas, karena jumlah guru yang nilainya berada pada kategori praktis lebih dari jumlah guru yang nilainya berada pada kategori tidak praktis, sehingga dapat disimpulkan LKPD tersebut memenuhi kriteria kepraktisan.

Tabel 5. Rekapitulasi Respon Peserta Didik Terhadap LKPD

\begin{tabular}{|c|c|c|c|c|c|c|}
\hline \multirow{2}{*}{ Aspek } & \multicolumn{5}{|c|}{ Peserta Didik } & Rata-Rata \\
\hline & 1 & 2 & 3 & 4 & 5 & \multirow{6}{*}{77,4} \\
\hline $\mathrm{A}$ & 11 & 12 & 12 & 11 & 12 & \\
\hline B & 35 & 35 & 34 & 35 & 36 & \\
\hline $\mathrm{C}$ & 16 & 15 & 16 & 16 & 16 & \\
\hline $\mathrm{D}$ & 15 & 16 & 14 & 16 & 14 & \\
\hline Jumlah & 77 & 78 & 76 & 78 & 78 & \\
\hline
\end{tabular}

Berdasarkan tabel 5 di atas, karena jumlah peserta didik yang nilainya berada pada kategori terbaca lebih dari jumlah peserta didik yang nilainya berada pada kategori tidak terbaca, sehingga dapat disimpulkan LKPD tersebut memenuhi kriteria keterbacaan.

Secara keseluruhan, hasil dari penelitian pengembangan ini menunjukan bahwa LKPD berbasis masalah open ended mencukupi kriteria valid dan layak untuk digunakan ditambah lagi LKPD juga memenuhi kriteria kepraktisan dan kriteria keterbacaan dengan berkaca dari hasil analisis uji respon guru dan peserta didik. Ini berekesesuaian dengan penelitian oleh Khairul dkk. (2018) yang menghasilkan LKPD berbasis masalah open ended poblem pada materi segi empat yang valid serta praktis. Dimana pada penelitian tesrsebut valid dapat disimpulkan karena nilai dari validator untuk segi isi, konstruksi, dan bahasa. Sedangkan kepraktisan terlihat dari hasil uji coba pada kelompok kecil yakni LKPD yang dibuat mudah untuk dimengerti oleh peserta didik. Penelitian pengembangan ini juga serumpun dengan penelitian yang dikerjakan oleh Yasmin (2019) yang menghasilkan LKPD pada materi statistika berbasis masalah open ended yang valid berdasarkan penilaian validator, serta keefektifan LKPD yang didapat dari persentase keberhasilan pengerjaan peserta didik sebesar 89\%, dan untuk kepraktisan LKPD didapat dari hasil angket respon peserta didik sebesar 81,7\%. 
Kelebihan dari LKPD ini adalah peserta didik bisa secara mandiri untuk belajar walaupun dalam pembelajaran daring untuk mengasah kemampuan berpikir kreativnya, menggunakan pengetahuan dan konsep matematika yang sudah mereka ketahui, kemudian menggunakanya untuk mencari penyelesaian masalah yang diberikan tanpa takut salah, karena masalah open ended yang disajikan merupakan masalah terbuka yang mana memungkinkan untuk peserta didik dapat menemukan beberapa penyelesaian yang benar. LKPD ini juga mudah diakses oleh peserta didik dan guru, LKPD juga jadi lebih menarik karena dirancang untuk pembelajaran daring yang bisa langsung dikerjakan oleh peserta didik secara online, dan guru bisa langsung melihat jawaban dari peserta didik.

Adapun kekurangan dari LKPD ini mungkin adalah keterbatasan dari media liveworksheets yang mana jawaban dari peserta didik tidak bisa berupa rumus, hanya bisa berupa kata-kata atau kalimat.

\section{SIMPULAN}

Penelitian ini memiliki hasil berupa LKPD berbasis masalah open ended pada materi trigonometri untuk menumbuhkan berpikir kreatif peserta didik kelas $\mathrm{X}$ dan menunjang pembelajaran daring yang valid melalui proses pengembangan. Pengembangan tersebut hanya dilakukan tiga tahap yaitu pendefinisian, perancangan, dan pengembangan.

Hasil analisis validitas dari tiga orang validator memperoleh tingkat kevalidan LKPD yang masuk kedalam kategori sangat valid. Hasil analisis angket respon dari lima orang guru LKPD memenuhi kriteria kepraktisan dan Hasil analisis angket respon dari lima orang peserta didik LKPD memenuhi kriteria keterbacaan

Untuk Peneliti selanjutnya (1) dapat melakukan uji coba LKPD yang sudah dikembangkan untuk mengetahui keefektifan dari LKPD yang sudah dikembangkan mengembangkan. (2) dapat mengembangkan LKPD berbasis masalah open ended untuk materi-materi lainnya dalam pelajaran matematika.

\section{REFERENSI}

Ariani, M. D., Candiasa, M., \& Marhaeni, A. (2014). Pengaruh Implementasi Open-Ended Problem Dalam Pembelajaran Matematika Terhadap Kemampuan. E-Journal Program Pascasarjana Universitas Pendidikan Ganesha, 4(1), 1-11.

Bahar, A., \& June Maker, C. (2015). Cognitive backgrounds of problem solving: A comparison of open-ended vs. closed mathematics problems. Eurasia Journal of Mathematics, Science and Technology Education, 11(6), 1531-1546. https://doi.org/10.12973/eurasia.2015.1410a

Çakır, H., \& Cengiz, Ö. (2016). The Use of Open Ended versus Closed Ended Questions in Turkish Classrooms. Open Journal of Modern Linguistics, 06(02), 60-70. https://doi.org/10.4236/ojml.2016.62006

I Trisnawati, W Pratiwi, P Nurfauziah, R. M. (2018). No Title. Analisis Kemampuan Berpikir Kreatif Matematis Siswa SMA Kelas XI Pada Materi Trigonometri Ditinjau Dari Self Confidence, 383-394. 
JP Becker \& S Shimada. (1997). The Open-Ended Approach: A New Proposal for Teanhing Mathematics. ERIC.

Khairul, F., Apertha, P., \& Yusup, M. (2018). PENGEMBANGAN LKPD BERBASIS OPENENDED PROBLEM PADA. 12(2), 47-62.

Kharisma, J. Y., \& Asman, A. (2018). Berorientasi pada Kemampuan Pemecahan Masalah Matematis dan Prestasi Belajar Matematika. Indonesian Journal of Mathematics Education, $1(1), 34$.

Livne, N. L. (2008). Enhancing Mathematical Creativity Through Multiple Solution to Open-Ended Problems Online. In National Educational Computing Conference, 1, 1-14. https://www.researchgate.net/publication/228862669_ENHANCING_MATHEMATICAL_CR EATIVITY_THROUGH_MULTIPLE_SOLUTIONS_TO_OPENENDED_PROBLEMS_ONLINE/link/5 4e4977a0cf2dbf60697061c/download

Nurcikawati, N. (2018). Rancang Bangun Media Pembelajaran Trigonometri Berbasis Multimedia Interaktif. SOSIOHUMANIORA: Jurnal Ilmiah Ilmu Sosial Dan Humaniora, 4(2), 114-121. https://doi.org/10.30738/sosio.v4i2.2766

Nuryadi, A., Santoso, B., \& Indaryanti, I. (2018). Kemampuan Pemodelan Matematika Siswa Dengan Strategi Scaffolding With A Solution Plan Pada Materi Trigonometri Di Kelas X SMAN 2 Palembang. Jurnal Gantang, 3(2), 73-81. https://doi.org/10.31629/jg.v3i2.468

Permanasari, V., Sugiarto, B., \& Kurniawati, I. (2013). Efektivitas Pendekatan Pembelajaran Open- Ended Terhadap Kemampuan Berpikir Matematis Siswa Pada Materi Trigonometri Ditinjau Dari Kreativitas Belajar Matematika Siswa. Pendidikan Matematika Solusi, 1(1), $31-38$.

Putra, S. (2019). Pengembangan LKPD Berbasis Open-Ended Problem Pada Materi Segiempat Kelas VII SMP Muhammadiyah 57 Medan.

S Akbar. (2017). Instrumen Perangkat Pembelajaran. PT Remaja Rosdakarya.

Yasmin, S. L. (2019). PENGEMBANGAN BAHAN AJAR LKPD PADA MATERI STATISTIKA BERBASIS MASALAH OPEN ENDED UNTUK KEMAMPUAN BERFIKIR KREATIF MATEMATIS SISWA KELAS VIII SMP NEGERI 5 JEMBER. UM Jember.

Yunian Putra, R. W., \& Anggraini, R. (2016). Pengembangan Bahan Ajar Materi Trigonometri Berbantuan Software iMindMap pada Siswa SMA. Al-Jabar: Jurnal Pendidikan Matematika, 7(1), 39-47. 